\title{
Standard Base Excess Measurement
}

National Cancer Institute

\section{Source}

National Cancer Institute. Standard Base Excess Measurement. NCI Thesaurus. Code C154721.

A calculated measurement of the amount of acid required to return blood with hemog lobin at $5 \mathrm{~g} / \mathrm{dL}$, which is used as a surrog ate for extracellular fluid, to a normal $\mathrm{pH}$ under standard conditions. 